\title{
Research
}

\section{Applying Retrospective Demographic Models to Assess Sustainable Use: the Maya Management of Xa'an Palms}

\author{
$\underline{\text { Andrea Martínez-Ballesté }}^{1}, \underline{\text { Carlos Martorell }}^{1}$, Miguel Martínez-Ramos $^{1}{ }^{1}$, and $\underline{\text { Javier Caballero }}^{1}$
}

\begin{abstract}
Xa'an palm (Sabal yapa) has been used to thatch traditional Maya houses for over 3000 years. In the Yucatan Peninsula, this palm has been introduced to pasturelands, maize fields (milpas), and homegardens. These and other traditional management systems are usually believed to be sustainable, but there is as yet little evidence to support this hypothesis. Demographic models have been used for this purpose, mainly focusing on population growth rate $(\lambda)$. So far, retrospective analysis has not been applied, even though it examines how changes in the the life cycle of a species, caused by different management regimes, affect its $\lambda$. In this study, we assess whether ecologically sustainable use of xa'an occurs in homegardens, pasturelands, and milpas, and if so, how it is achieved. We constructed matrix population models for four populations of xa' an that were followed for 3 years, and then conducted a retrospective analysis on them. Management in homegardens seems to be oriented to increasing the availability of xa' an leaves, favoring the survival of seedlings, and increasing the density of harvestable-sized palms. However, in the milpa and the pastureland, the population size structure resembles that of unmanaged populations. Our $\lambda$ values suggest that the traditional use of xa' an in all the studied management regimes is sustainable. Nevertheless, the processes that lead to sustainable use are different in each system, as shown by our retrospective analysis. Although fecundity contributes positively to $\lambda$ only in homegardens, permanence and growth maintain palm populations at an equilibrium in the pastureland and in the milpa, respectively. Between-year climatic differences had a smaller impact on $\lambda$ than management practices, which may vary from one year to another, leading to different balances in the sustainable use of the populations involved. Even though no significant differences were found in $\lambda$ values, Maya achieve sustainable use of xa' an palm under diverse scenarios by managing the great plasticity of the species, as was revealed by the retrospective analysis. Hence, this approach proved to be effective, not only for assessing sustainable use, but also for understanding the factors that favor or limit it.
\end{abstract}

Key Words: Ethnoecology; LTRE; Mexico; NTFP; Sabal yapa; traditional management; xa\&\#8217an palm; Yucatan.

\section{INTRODUCTION}

Numerous studies suggest that sustainable use in traditional management systems is possible because such systems have stood the test of time, and because they involve a close relationship between local peoples and their environment (Haverkort and Millar 1994, Turner et al. 2000). However, there is still little evidence on whether sustainability is favored or limited by such practices (Grenand and Grenand 1996, Berkes et al. 2000).

Sustainability is still a controversial concept, and has been defined in several ways; different parameters have been suggested as a basis for its measurement (Lubchenco et al. 1991, Levin 1993, Kates et al. 2001, Swart et al. 2002, Newton and Freyfogle 2005, Padoch and Sears 2005). In this paper, we focus on sustainable use, which-from an ecological perspective-may be achieved if the management of a resource allows its natural replacement, so it is capable of renewing itself indefinitely (Mangel et al. 1993). At the population level, this has been equated with keeping the finite growth rate $(\lambda)$ of the managed species' population at or above its equilibrium value (i.e., $\lambda \geq 1$, e.g., Olmsted and Álvarez-Buylla 1995, Joyal 1996, Ticktin et al. 2002). Growth rate is estimated from 
demographic models that project the hypothetical consequences of the present environmental conditions and management practices over longterm periods under the assumption that these remain unchanged.

The persistence of the exploited populations under traditional management will depend not only on ecological processes, but also on the characteristics of the production system (Homma 1996). For example, two management strategies may have the same effect on $\lambda$ although their relative effects on growth, survival, and fecundity may differ. The response of $\lambda$ to different human activities may then be adequately analyzed by retrospective analysis (Ehrlén and van Groenendael 1998). This method has been used to compare populations under different spatial and temporal environmental scenarios, identifying, in each situation, those stages of the life cycle that, relatively, contribute the most to the observed variation in $\lambda$ (Caswell 1989, Horvitz et al. 1997). This analysis has not been used in assessments of sustainable use, even though it could be a powerful tool to evaluate the effect of management on population dynamics.

Prospective analyses such as elasticity, evaluate the relative effects on vital rates of hypothetically small changes in the environment or in management, assuming that they remain unaltered over time (Caswell 2001). Management systems, however, adapt to changing environmental and sociocultural scenarios. Retrospective models allow us to analyze actual differences between management regimes and, eventually, to establish the general principles by which sustainable use may be achieved under different conditions.

An appropriate system to analyze the effect of different management regimes on a single biotic resource is that of leaf harvest of xa' an palm (Sabal yapa Wright ex Becc., Arecaceae). This species has been managed for over 3000 years by the Yucatec Maya of Mexico (Caballero 1994). The most important use of xa'an leaves is for roof thatching the traditional Maya house. The regime in which these palms have been managed has evolved as a result of a number of linking factors, including cultural change, human population growth, and changes in land use. Time has not substituted one management regime for another, but, rather, the result has been their accumulation and integration into the wide technological scenario found today throughout the Yucatan Peninsula (Caballero
1994). There are four different regimes of xa'an palm management: in the state of Quintana Roo, it is harvested in both the mature and the secondary forest; in the maize-growing region of the states of Quintana Roo and Yucatan, xa' an is spared in maize fields; in the cattle-raising region of Yucatan, it is spared in pasturelands; and throughout the Maya area of the peninsula, xa'an is also maintained or promoted in homegardens (Caballero 1994), which are complex agroforestry systems that combine a great variety of trees and shrubs, both wild and cultivated (Caballero 1992).

In this study, we conducted a demographic retrospective analysis to assess whether xa' an palm is being managed in an ecologically sustainable manner in home gardens, pasturelands, and milpas, and if so, how is it achieved. This last issue has not been quantitatively assessed. In particular, we approached the following questions: Does population density and structure of xa'an palm differ among management regimes? How much does $\lambda$ vary among management regimes? Which palms' vital rates contribute more in observed $\lambda$ variation among management regimes and years? Do these management regimes result in sustainable use, and if so, how is it achieved?

\section{METHODS}

This study was carried out in three different settlements that represent the different regimes of xa'an management in the present Maya area of the Yucatan Peninsula (Fig. 1). In the town of Maxcanú, xa'an palm is abundant in most homegardens. The entire homegarden is watered and weeded regularly. $\mathrm{Xa}$ 'an seeds are occasionally sowed, seedlings are protected from livestock, and larger palms are frequently harvested in order to increase leaf production. Although commercial demand is very low, household demand is the highest among the three study sites because there are more buildings thatched with palm in each homegarden. It is also the largest town of the three (Gama 2001, MartínezBallesté et al. 2002).

The town of Sucila is located in the cattle-raising zone of Yucatan. In this town, xa' an individuals are spared when new pasturelands are opened, but receive no special care afterward. As in Maxcanú, leaf harvest is constant. Palms are damaged by fires initiated by ranchers who want to promote pasture, by cattle grazing, and by the very high irradiance 
Fig. 1. Location of the study sites and annual precipitation for 1998 (gray bars), 1999 (black bars), and 2000 (white bars) in a) Maxcanú, b) Sucilá, c) X'Konhá, and d) average for the three sites.
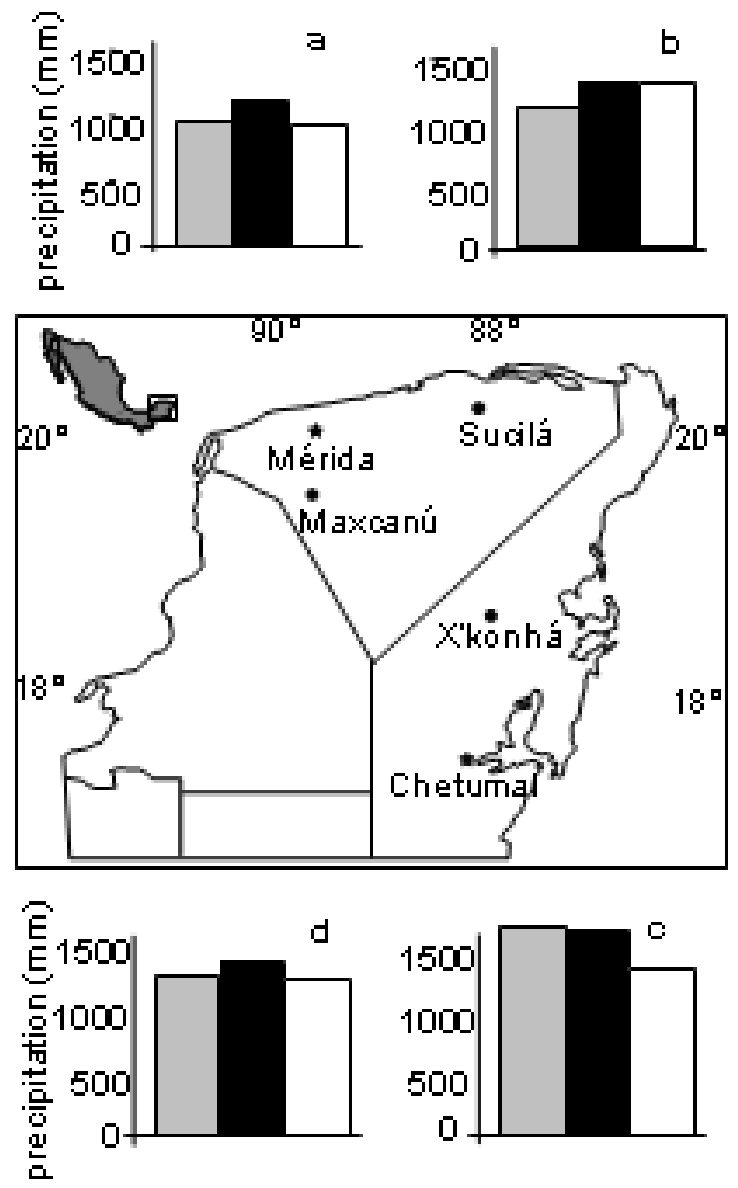

that kills seedlings and saplings. Although the leaves are used locally, domestic leaf demand is the lowest (Gama 2001, Martínez-Ballesté et al. 2002). Commercial harvest does take place, but it is not important to local economy.

In X'Konhá, xa'an grows along with maize and various vegetables and fruit trees in permanent agricultural fields locally known as milpas. As in Sucilá, palms do not receive any care other than being spared when the forest is felled in order to establish the milpa. Leaf harvest is constant. The area is burned occasionally to remove unwanted vegetation and sow maize, and small numbers of livestock feed on xa'an. Irradiance is very heterogeneous. Domestic leaf demand is intermediate, and household production is seldom sold (Gama
2001, Martínez-Ballesté et al. 2002). In the three management systems, harvest takes place without felling the palms. Only mature leafs are cut, leaving one to three younger leaves and the meristem intact.

As well as being directly affected by human activity and by micro-environmental differences of each system, xa'an populations may also be influenced by climatic variations. A northwest-southeast temperature and precipitation gradient in the Yucatan Peninsula (Miranda 1958) corresponds to a vegetation gradient that goes from dry forest in the NW region of the peninsula, to rainforest in the SE. Maxcanú and Sucilá are in the warm and dry region, whereas $\mathrm{X}^{\prime}$ Konhá is located in the region with the highest precipitation (see Fig. $1 \mathrm{a}, \mathrm{b}, \mathrm{c}$ ). Although hurricanes are an important phenomenon 
in the peninsula, during the course of our study, we did not observe their effect on xa' an populations.

\section{Demographic Data}

Although milpas and pasturelands seemed quite homogeneous, homegardens are highly variable (Caballero 1994). Four sites were selected for this study, two in homegardens, one in pastureland, and one in a milpa. The pastureland and the milpa were larger (3.9 ha and 1.7 ha, respectively) than both homegarden-1 (0.61 ha.) and homegarden-2 (0.25 ha.). Homegarden-1 was irrigated, whereas homegarden-2 depended fully on rainfall, representing two very contrasting systems. Between 161-239 individuals of xa'an palm were sampled by means of randomly established permanent plots of different length depending on the size class of palms in each site. Palm individuals were classified into nine categories, according to their size and development stage, as follows: seedlings (SD, newborn palms less than 1 year old); saplings with belowground stems and a leaf morphology different from that of seedlings, further divided into three categories-SA1 (bifid leaves), SA2 (incompletely divided leaves), SA3 (completely divided leaves); juveniles with aboveground visible stems and encompassing next stem length (from the ground to the apical meristem) categories (range in centimeters) J1 (1-50), J2 (51-100), J3 (101-200), and J4 (201-300); and adults (reproductive individuals) divided in next stem length categories (range in centimeters) A1 (301-400), A2 (401650), A3 (651 or more). The most commonly harvested size classes are the juveniles and the shorter adults.

Survival and growth were recorded annually between January 1998 and January 2001. Seedling survival was recorded every 6 months, and those surviving for a year after germination were considered recruited. Palms do not form a seed bank (Vázquez-Yanes and Orozco-Segovia 1993, Svenning 2001), so it was assumed that all seeds either germinate within a year or die.

The basal area of the inflorescence's principal axis in each reproductive individual was measured yearly. This provided an estimation of the number of fruits produced. Based on previous data, we knew that there is a strong correlation between the basal area of the branches and the sum of the basal areas of the branches stemming from them $(r=0.99)$, and that the basal area of a fruit-bearing branchlet determines the number of fruits it produces $(r=$ 0.81).

The average fecundity for each category was calculated according to the Menges (1990) empirical approach, in which the recruited seedlings are assigned to each adult category according to the proportion of total reproductive effort made by the category, and by the number of individuals it contains. As no record was made of the mortality of the largest adults, the respective survival probability was estimated from the growth rate (which was found to have values between 12.5 and $28 \mathrm{~cm}_{\text {year }}{ }^{-1}$ at the different sites and years) and the maximum observed height, assuming that death occurred after maximum height was achieved (Mendoza 1995).

Stasis, growth, and fecundity rates were used to establish matrix population models for each site and each of the 3 years studied. Stasis values can be seen in the matrix diagonal, and correspond to individuals that remain in the same size category after 1 year. Growth values are found under the diagonal, and they refer to individuals that move to the next size category. Adult fecundity values are found on the first line of the matrix (Appendix 1). These models were iterated until stability was reached to obtain $\lambda$ values as described in detail in Caswell (2001). Confidence intervals for each obtained $\lambda$ were set through a Series Approximation Method (Caswell 2001).

\section{Retrospective Analysis}

Management and environmental variations in the dynamics of xa' an palm populations, and their effect on population growth rate $(\lambda)$ were analyzed by means of retrospective analysis. As it occurs in conventional analyses of factorial experiments, retrospective analysis partitions the observed variations in $\lambda$ into main effects caused by two factors, site and year, and their interaction. The effect of these factors on $\lambda$ was further broken down into the contributions from the observed differences in each vital rate (Caswell 1989). Contributions are additive, so matrix entries with positive contributions correspond to intersite and interannual variations in vital rates that tend to increase the $\lambda$ value, whereas negative contributions decrease $\lambda$, and zeros have no effect (Appendix 2). Contributions were summarized by adding up the values of all entries in the matrix corresponding to 
each of the three fundamental demographic components: stasis, growth, and fecundity.

\section{RESULTS}

Palm density was similar at all sites except the milpa, where it was lower (Fig. 2). Seedlings were the most abundant size class in all populations (Fig. 2) but significant differences $\left(\chi^{2}=92.01, p<\right.$ $0.0001)$ in size structure were observed between sites. Pastureland and milpa had higher proportions of SA1 and A individuals, but the more frequently harvested size classes (juveniles) were relatively more abundant in homegardens (Fig. 2). This results in a much higher density of useful individuals (juveniles and adults - 1) in the latter system.

\section{Matrix Models and Finite Population Growth}

Survival of seedlings was particularly high in homegardens and in the milpa during the 3 years (77\% in homegarden-1, 78\% in homegarden-2, and $88 \%$ in the milpa). In contrast, only $24 \%$ of the seedlings survived in the pastureland. Adult mortality was only observed in homegarden-1, where the householders removed a few of them in order to clear space to build a house. The lowest average stem growth for all size categories was recorded in homegarden-1, and the highest one in the milpa (Appendix 1). Nevertheless, the probabilities of stasis are higher in all categories (between 60\%-99\%) than the probabilities of moving into the next stage (between 3\%-40\%). Growth of these palms is, therefore, slow; it takes approximately 7 years for a palm to reach the size of a juvenile individual, and they have a total lifespan of $\sim 100$ years.

During the 3 years studied, the highest seedling recruitment was recorded in homegardens (458 and 462 seedlings in homegardens- 1 and -2 vs. 45 in pastureland and 275 in the milpa) despite the reduced fruit production per individual recorded there in the same time period (2449 and 11871 in homegardens- 1 and -2, respectively, vs. 35557 in the pastureland and 31722 in the milpa). As a result, the fecundity calculated for the projection matrices was higher in the homegardens (Appendix 1).

The among-year average transition matrices for each site $(95 \%$ confidence interval) give the following $\lambda$ values: $1.007(0.92-1.09)$ and 1.092 (0.99-1.19) for homegardens- 1 and -2 , respectively, $1.072(0.92-1.22)$ for the milpa, and 1.017 (0.981.05) for the pastureland. The estimated confidence intervals indicate that the population growth rates did not differ from 1 , and that $\lambda$ did not differ between populations.

\section{Retrospective Analysis}

In the homegardens and in the pastureland, stasis made an important positive contribution to differences in $\lambda$, but not at the milpa, where overall individual growth contributed positively to $\lambda$ (Fig. $3 a-d)$. The overall differences in growth and stasis contributions were largely concentrated in the seedling and sapling stages, which made large positive contributions in the two homegardens, and negative ones in the pastureland (Appendix 2, site contributions). Fecundity contributes positively to $\lambda$ in the homegardens (Fig. 3a, b), but negatively in the pastureland and in the milpa (Fig. 3c, d). Only in homegarden-2, stasis, growth, and fecundity contributed positively to population growth, therefore, the highest $\lambda$ was obtained there (Fig. 3b).

There were nearly no differences in average $\lambda$ between years, so annual variation was less important than between site variation (Fig $3 \mathrm{e}-\mathrm{g}$ ). A positive contribution of the individuals' growth to $\lambda$ was observed in 1999 , when the average precipitation was highest $(1328 \mathrm{~mm})$ (Fig. 3f). In contrast, in 1998 and 2000, the years with the lowest average precipitation $(1215$ and $1175 \mathrm{~mm}$, respectively), individuals barely grew and $\lambda$ resulted from individuals' stasis (Fig. 3e, g). In 1998 , fecundity also contributed to an increase in $\lambda$ values. The life stages most affected by climatic variation and responsible for the greatest contributions to $\lambda$ were fecundity, and seedling and sapling growth (Appendix 2, year contributions).

The interaction between sites and years produced a contribution to $\lambda$ values comparable to that of sites. However, no clear pattern was readily apparent (Fig. 3h-s). In 1998, stasis in both homegardens was mostly responsible for the observed $\lambda$ value (Fig. $3 \mathrm{~h}, \mathrm{k})$, whereas growth and fecundity were the most important parameters in the pastureland and in the milpa, respectively (Fig.3n, q). In 1999, growth was important in homegarden-2 (Fig. 3 1), but stasis made a larger contribution in homegarden- 1 and in the milpa (Fig. 3i, r), and all three demographic 
Fig. 2. Palm density and population structure. The $+/-$ symbols indicate significant differences after a Haberman-adjusted residual test $\left(\chi^{2}=92.01, p<0.0001\right)$.

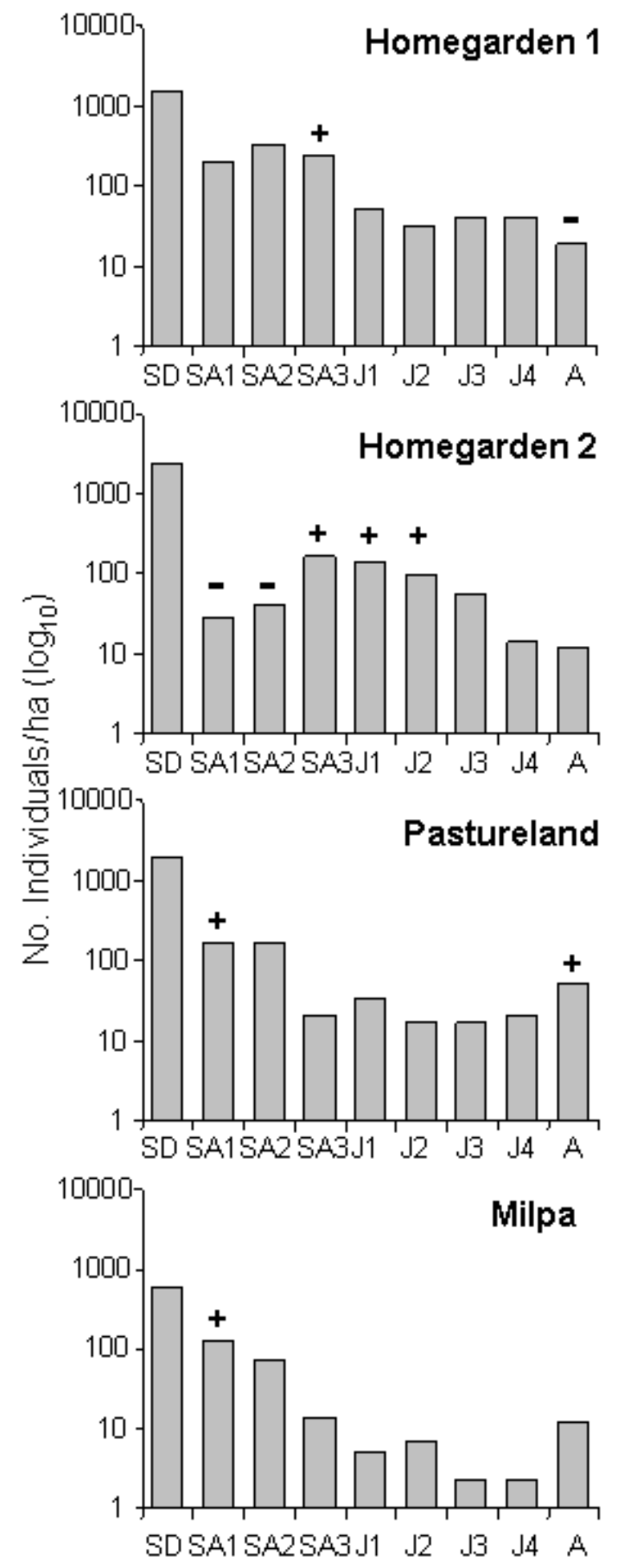


Fig. 3. Vital rate (stasis, growth, and fecundity) contributions to the difference between the populations' finite growth rates, $\lambda$. Differences are broken down into site contributions (a-d), year contributions (e$\mathrm{g}$ ), and site $\mathrm{x}$ year interactions (h-s). In the latter, sites are arranged in rows and years in columns.

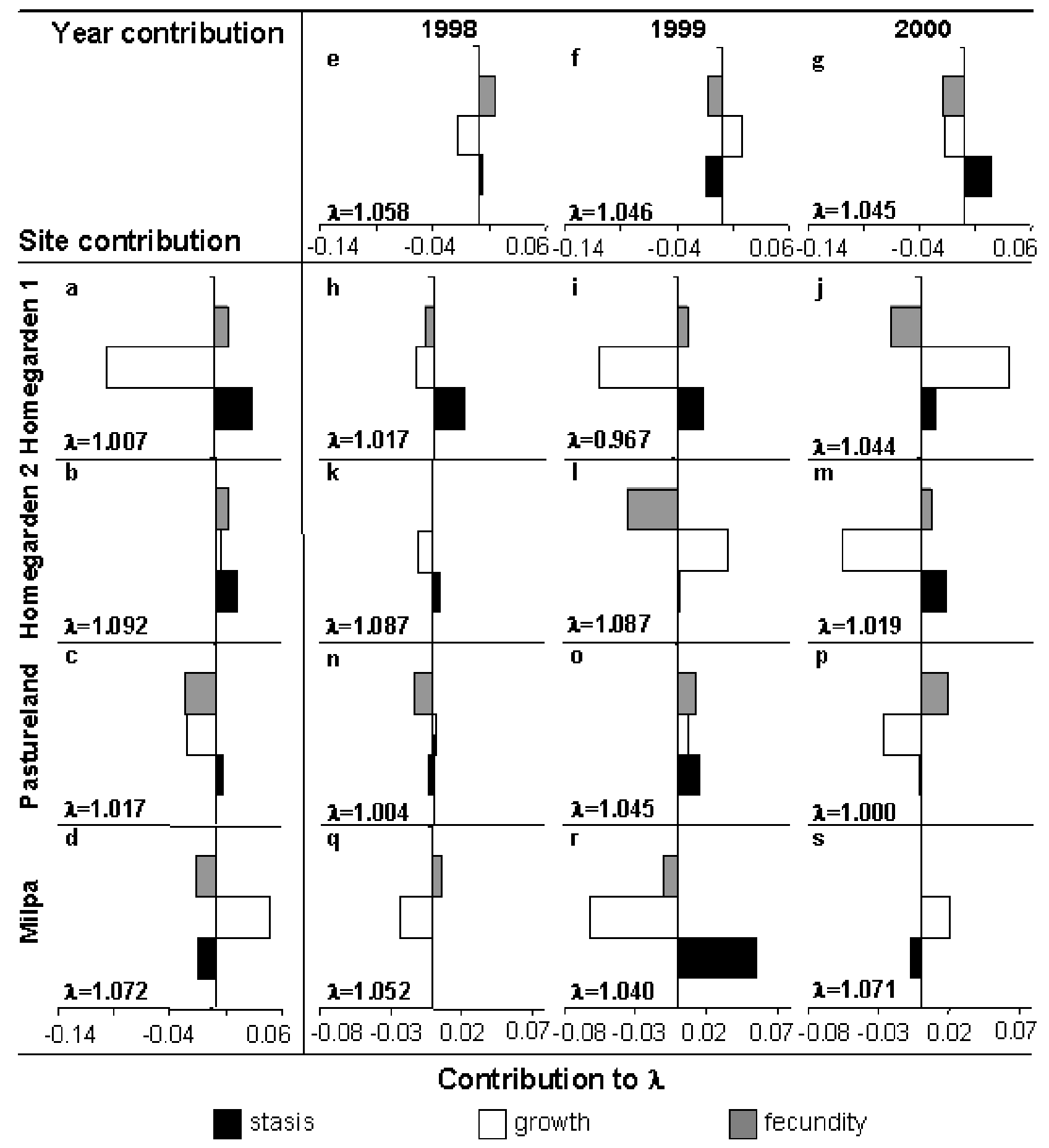


components made positive contributions in the pastureland (Fig. 3o). Finally, in 2000, growth had a large positive contribution to $\lambda$ in homegarden-1 and in the milpa (Fig. 3j, s), but a large negative one in homegarden-2 and the pastureland, where fecundity had the largest contribution (Fig. $3 \mathrm{~m}$, and p; Appendix 2, site $\times$ year contributions).

\section{DISCUSSION}

Population density and structure of xa'an palm under different management regimes show a close relationship with predominant land use and leaf demand. In Sucilá and in X'Konhá, local leaf demand is easily met because palms are available in extensive areas of pastureland, milpas, and forest (Gama 2001, Martínez-Ballesté et al. 2002). In these conditions, Maya farmers do not take much care of xa' an palms; they just leave them standing without any further protection when clearing areas for agriculture or cattle raising. In contrast, in Maxcanú, where demand for leaves is higher (Gama 2001, Martínez-Ballesté et al. 2002), there is no more forest, and the traditional milpa where xa' an grew has disappeared, therefore the homegardens are the only space where xa' an palms can be harvested. In homegardens, Maya cultivators may carry out a series of management activities that do not take place on the other sites, such as planting seeds or protecting seedlings, saplings, and juvenile individuals. Watering fruit trees planted in the homegardens may provide better growing conditions for xa'an palms, thus maximizing leaf availability. As land use intensifies and natural stocks of palm decrease or become more distant on the Yucatan Peninsula, plant resource management becomes more complex and sophisticated. This same process has also been observed in other regions of the world (Arnold and Dewees 1995), and is proposed as an alternative to increase the production of palm leaves that are harvested from natural vegetation (Svenning and Macías 2002).

Management in homegardens seems to be oriented to increasing the availability of xa' an palm leaves in small spaces, favoring seedling survival, and increasing the density of palms. The overall population density of xa'an was higher in the homegardens than in the milpa, but similar to that of the pastureland. However, it must be considered that the proportion of juveniles was significantly higher in the homegardens. In the milpa and in the pastureland, the harvestable juveniles are scarcer, and most individuals are unusable seedlings and saplings (Fig. 2), showing the inverted-j size structure typical of wild, unmanaged palm populations (Piñero et al. 1984, Ramp 1989, Ratsirarson et al. 1996). Thus, the higher density of juveniles in the homegardens seems to be the result of a management action oriented to maximize the availability of xa' an leaves in the small land area that is characteristic of homegardens.

In terms of the long-term persistence of managed xa'an palm populations and, therefore, of the enduring availability of palm leaves, our demographic analysis suggests that the traditional use of xa' an palms, in any of the studied sites, is sustainable $(\lambda \geq 1)$. This is despite the environmental and management differences existing in the studied sites. Nevertheless, the processes that lead to sustainable use are different in each land-use type, as shown by our retrospective analysis. The reduced size of our sample does not allow us to state that use is sustainable in any milpa, pastureland or homegarden throughout the Maya area of Yucatan, but the case studies that we compared are so dissimilar that they may be representative of a wide range of practices under which sustainable use is achieved.

The greater harvesting intensity occurring in Maxcanú may be responsible for the diminished fruit production in homegardens, as it happens with other palm species (Flores and Ashton 2000, Zuidema and Werger 2000, Endress et al. 2004). Nevertheless, the increased survival of seedlings (an important component of the fecundity estimates, see Methods) was favored by the gardening activities. Thus, fecundity was an important vital rate in maintaining the populations at equilibrium in both homegardens (fig. 3a, b vs. fig 3c,d). Some practices carried out by Maya cultivators in the homegardens, such as watering fruit trees and protecting palms from grazing and trampling by domestic animals, may improve seedling establishment. In largeseeded species, such as those of xa'an palms, establishment may also be favored by the shade provided by tree canopies (Popma and Bongers 1988, Martínez-Ramos 1994), which seems to be the case in the shady environment created by usable trees grown in homegardens. In contrast, fecundity had a negligible contribution to $\lambda$ in the other landuse types. In milpas as in pastureland, with no management activities to protect the seedlings, establishment and survival become difficult because of sun exposure (e.g., damage associated 
with livestock activity in pasturelands and weeding in milpas), and periodic intentional burning (Salisbury and Ross 1992, Araus and Hogan 1994).

Even within the same management regime, there may be important variations in population dynamics. This was the case for the two homegardens, where sustainable use is achieved through a different balance of vital rates (Fig. 3 a, b). Because both homegardens have virtually the same climate and soil, the observed demographic difference may be mostly attributable to differences in the decisions taken by the owner. The shady understorey created in homegarden- 1 by high tree densities, although beneficial to seedlings, seems to slow down plant growth (Augspurger 1984, Bongers and Popma 1990, Svenning 2001). Saplings and juveniles in this place (Fig. 3a) grew less than in the other sites. This condition is an advantage for Maya cultivators because slow growth maintains palms short for a longer period, allowing for an easier leaf harvesting. At the same time, as occurs with other palm species (Joyal 1996, O'Brien and Kinnaird 1996, Svenning and Macías 2002, Flores and Ashton 2000, Zuidema and Werger 2000), slow growth may have a strong negative effect on leaf productivity and on long-term population growth, as revealed by its large negative contribution to $\lambda$.

Life-history theory suggests that organisms that grow under different environments may develop different strategies (Grime 1979, Stearns 1992). The results of retrospective analysis show that xa'an palm has a great ability to adapt to diverse ecological and management scenarios. Although fecundity contributes positively to $\lambda$ only in homegardens, stasis and growth make an important contribution to maintaining palm population at an equilibrium in the pastureland and in the milpa, respectively. The observed differential contribution of stasis, fecundity, and growth to $\lambda$ in the studied xa'an populations grossly corresponds to the three contrasting life-history strategies proposed by Grime (1979) and discussed by Silvertown et al. (1993) in a demographic context. Therefore, xa'an palm's behavior resembles that of a tolerant plant in the pastureland, of a competitor in the milpa, and of a ruderal plant in the homegardens. This suggests that Maya cultivators may take advantage of lifehistory plasticity to achieve a sustainable use of xa'an under different land-use types. Although it has been proposed that plasticity favors sustainable use (Wollenberg 1998), quantitative evidence, as presented here, has been lacking.

Our results show that between-year climatic variations within the studied period did have a minor effect on the populations' growth rates. This may be the result of the lack of a strong consistent climatic pattern throughout the peninsula. Only 1999 was consistently humid everywhere (Fig. 1 a, b, c), and xa'an plants grew more (Fig. 3f). Other species of palms such as Sabal uresana (Joyal 1996) and Chamaedorea radicalis (Endress et al. 2004) produce more leaves during the rainy season and, as a result, there is an increase in photosynthetic activity and, therefore, an increase in palm growth (Svenning 2001). Stasis showed the opposite pattern, becoming more important for the maintenance of $\lambda$ when average rainfall diminishes (Fig. 3e, g, and Fig. 1d). The behavior of fecundity did not show any clear rainfall-related pattern.

As shown by the site $\times$ year interaction, the lack of a strong contribution by the year factor may also be explained by management actions buffering between-year climatic variability. For example, in homegarden-1 (Fig. 3j), manual irrigation decreased the negative impact of the driest year in Maxcanú (2000), allowing individuals and the overall population to grow more in that year than in any other year. The opposite behavior was observed that same year in the non-irrigated homegarden-2 (Fig. 3m). In contrast, year 2000 was the wettest year in Sucilá (Fig.1b), but it had no positive impact on $\lambda$ because the landowner decided to burn the pastureland that year (Fig. 3p).

Site $\times$ year interaction also shows how population dynamics are mostly the result of yearly changes in management that are not necessarily related to xa' an use, but to agroforestry system practices as a whole. For example, although growth was higher in the rainiest year in homegarden-2 (Fig. 3 l), stasis was more important in the milpa population during the rainiest year because this system is promoted by the practice of burning (Fig. 3r). Removal of adult palms for building purposes (Fig. 3i), or renewal of pasture by means of fire (Fig. 3p), may sporadically have a negative impact on xa' an population growth, as has been found with other palm species (Piñero et al. 1984, Olmsted and Álvarez-Buylla 1995, Joyal 1996, Ratsirarson et al. 1996). Xa'an population growth rate responds more strongly to between-year variations in management in homegardens, 
probably because of how closely the palm is tied to the householders' multiple needs and activities, and to eventualities in the management practices. For example, in homegarden- 2 a mentally ill member of the household severely overharvested the palms in 2000 , resulting in the lowest $\lambda$ observed on that site (Fig. $3 \mathrm{~m}$ ). Although overharvesting is rare, the events that took place in homegarden- 2 in 2000 show how leaf production and, eventually, sustainable use, may be compromised when the plasticity of the species is exceeded. Even though palms are highly tolerant to defoliation and may recover rapidly (Zuidema and Werger 2000), overharvesting and the subsequent reduction in the individual growth rates may reduce $\lambda$, as happens in palms such as Astrocaryum mexicanum (Mendoza et al 1987), Sabal uresana (Joyal 1996), Geonoma macrostachys (Svenning and Macías 2000), Geonoma deversa (Zuidema and Werger 2000), and Chamaedorea radicalis (Endress et al. 2004).

This is a warning about what may happen if use is intensified. The increased demand posed by the resorts in Cancun (Caballero et al. 2004) or an increase in local use could lead to a decrease in xa' an populations and in leaf availability. So far, the plasticity of the species and the adaptive management conducted by the Maya seem to have successfully overcome these new threats.

\section{Final Considerations}

Up until now, prospective demographic studies have been the tool most used to evaluate sustainability in a managed population. Their contribution has been important in evaluating the possible long-term upkeep of populations, assuming that present conditions are constant or under potential scenarios. This tool has laid the basis for trying to prove the hypothesis that traditional management of non-timber forest products (NTFP) is characterized by the assurance of the persistence of the resource stock. Nevertheless, little emphasis has been placed on the way in which this can be achieved. The complexity and dynamics of traditional management systems, and their effect on the sustainable use of resources, can be evaluated by means of a retrospective analysis. In this study, we used this technique to analyze the variation caused in $\lambda$ by the effect of actual changes occurring under different environmental and management scenarios. Our results show that sustainable use can be achieved in several ways. A group of systems could be sustainably managed in some places, but not in others, and this tool could allow us to evaluate what causes the difference. The development of more studies, focused not only on the persistence of the resource but also on the way that changes in management favor or limit such persistence, would allow us to answer basic questions, such as how is sustainability achieved in traditional systems, which phases of the life cycle should be managed under different conditions, or what are the alternatives in the face of a particular problem. This would provide us with new guidelines in our search for sustainable use.

Responses to this article can be read online at: http://www.ecologyandsociety.org/vollo/iss $2 /$ art17/responses/

\section{Acknowledgments:}

The present study was funded by CONABIO (Project M111), CONACyT (Project 31846-B), which, along with the Universidad Nacional Autónoma de México, also gave a Ph.D. grant to the first author. Librada Kumul, María Belem, Buenaventura Lugo, Blas Balam, and their families allowed us to work on their lands and always welcomed us affectionately. We also wish to thank the municipal authorities of Maxcanú, Sucilá, and X'Konhá, Salvador Flores and Juan Tun at the Universidad Autónoma de Yucatán, and the Botanical Garden and Biology Institute of the Universidad Nacional Autónoma de México for logistical support. Luis Salinas, Valeria Gama, Gustavo Martínez, and Tere Pulido helped us with the field work. María del Carmen Mandujano, Ana Mendoza, Hermilo Quero, and Ken Oyama gave us valuable insight into plant demography and palm biology.

\section{LITERATURE CITED}

Araus, J. L., and P. Hogan. 1994. Leaf structure and patterns of photoinhibition in two neotropical palms in clearings and forest understory during the dry season. America Journal of Botany 81:726-738.

Arnold, J. E. M., and P. A. Dewees. 1995. Tree management in farmer strategies: responses to agricultural intensification. Oxford University, 
Oxford, UK.

Augspurger, C. K. 1984. Light requirements of neotropical tree seedlings: a comparative study of growth and survival. Journal of Ecology 72:777795.

Berkes, F., J. Colding, and C. Folke. 2000. Rediscovery of traditional ecological knowledge as adaptive management. Ecological Applications 10 (5):1251-1262.

Bongers, F., and J. Popma. 1990. Leaf dynamics of seedlings of rain forest species in relation to canopy gaps. Oecologia 82:122-127.

Caballero, J. 1992. The Maya homegardens of the Yucatan Peninsula: past, present and future. Etnoecologica 1(1):35-54. (Online.) URL: http://w ww.etnoecologica.org.mx/Etnoecologica vol1 n1/ frame sup art cab1.htm.

1994. Use and management of sabal palms among the Maya of Yucatan. Dissertation, University of California, Berkeley, California, USA.

Caballero, J., M. T. Pulido, and A. MartínezBallesté. 2004. El uso de la palma de guano (Sabal yapa) en la industria turística de Quintana Roo, México. Pages 365-386 in M. Alexiades and P. Shanley. Productos forestales, medios de subsistencia y conservación. Estudios de caso sobre sistemas de manejo de productos forestales no maderables. Center for International Forestry Research (CIFOR), Bogor, Indonesia.

Caswell, H. 1989. Analysis of life table response experiments I. Decomposition of effects on population growth rate. Ecological Modelling 46:221-237.

2001. Matrix population models. Construction, analysis, and interpretation. Sinauer Associates, Inc., Sunderland, Massachusetts, USA.

Ehrlén, J., and J. van Groenendael. 1998. Direct perturbation analysis for better conservation. Conservation Biology 12(2):470-474.

Endress, B. A., D. L. Gorchov, M. B. Peterson, and E. P. Serrano. 2004. Harvest of the palm Chamaedorea radicalis, its effects on leaf production, and implications for sustainable management. Conservation Biology 18(3):822830.

Flores, C. S., and P. M. S. Ashton. 2000. Harvesting impact and economic value of Geonoma deversa, Arecaceae, an understory palm used for roof thatching in the Peruvian Amazon. Economic Botany 54(3):267-277.

Gama, V. 2001.Demanda y Disponibilidad de la palma de guano (Sabal spp., Arecaceae) en tres comunidades de la Península de Yucatán. Thesis, Universidad Nacional Autónoma de México, Mexico, Mexico.

Grenand, P., and F. Grenand. 1996. Living in abundance. The forest of the Wayampi (Amerindians from French Guiana). Pages 177-196 in P. M. Ruiz-Pérez and J. E. M. Arnold. Current issues in non-timber forest products research. Center for International Forestry Research, Bogor, Indonesia.

Grime, J. P. 1979. Plant strategies and vegetation processes. John Wiley, Toronto, Ontario, Canada.

Haverkort, B., and D. Millar. 1994. Constructing diversity: the active role of rural people in maintaining and enhancing biodiversity. Etnoecologica 2(3):51-63. (Online.) URL: http://www.etnoecolog ica.org.mx/Etnoecologica vol12 n3/art haven.htm

Homma, A. K. O. 1996. Modernization and technological dualism in the extractive economy in Amazonia. Pages 59-81 in M. Ruiz-Pérez and J. E. M. Arnold. Current issues in non-timber forest products research. Center for International Forestry Research (CIFOR), Bogor, Indonesia.

Horvitz, C., D. W. Schemske, and H. Caswell. 1997. The relative "importance" of life-history stages to population growth: prospective and retrospective analyses. Pages 247-271 in S. Tuljapurkar and H. Caswell. Structured population models in marine, terrestrial and freshwater systems. Chapman and Hall, New York, New York, USA.

Joyal, E. 1996. The palm has its time: an ethnoecology of Sabal uresana in Sonora, Mexico. Economic Botany 50(4):446-462.

Kates, R. W., W. C. Clark, R. Corell, J. M. Hall, 
C. C. Jaeger, I. Lowe, J. J. McCarthy, H. J. Schellnhuber, B. Bolin, N. M. Dickson, S. Faucheux, G. C. Gallopin, A. Grübler, B. Huntley, J. Jäger, N. S. Jodha, R. E. Kasperson, A. Mabogunje, P. Matson, H. Mooney, B. Moore, T. O'Riordano, and U. Svedin. 2001. Environment and development: sustainability science. Science 292(5517):641-642.

Levin, S. A. 1993. Forum, science and sustainability. Ecological Applications 3 (4):545546.

Lubchenco, J., A. M. Olson, L. B. Brubaker, S. R. Carpenter, M. M. Holland, S. P. Hubbell, S. A. Levin, J. A. MacMahon, P. A. Matson, J. M. Melillo, H. A. Mooney, C. H. Peterson, H. R. Pulliam, L. A. Real, P. J. Regal, and P. G. Risser. 1991. The sustainable biosphere initiative: an ecological research agenda. Ecology 72(2):371412.

Mangel, M., R. J. Hofman, E. A. Norse, and J. R. Twiss. 1993. Sustainability and ecological research. Ecological Applications 3(4):573-575.

Martínez-Ballesté, A., J. Caballero, V. Gama, S. Flores, and C. Martorell. 2002. Sustainability of the traditional management of $X a$ 'an palms by the lowland Maya of Yucatan, México. Pages 381-388 in Proceedings of VII International Congress of Ethnobiology "Ethnobiology, benefits sharing and biocultural diversity." Athens, Georgia, 2000. International Society of Ethnobiology, Athens, Georgia, USA.

Martínez-Ramos, M. 1994. Regeneración natural y diversidad de especies arbóreas en selvas húmedas. Boletín de la Sociedad Botánica de México 54:179-224.

Mendoza, A. 1995.Demografía e integración clonal en Reinhardtia gracilis, una palma tropical. Dissertation, Universidad Nacional Autónoma de México, Mexico, Mexico.

Mendoza, A., D. Piñero, and J. Sarukhán. 1987. Effects of experimental defoliation on growth, reproduction and survival of Astrocaryum mexicanum. Journal of Ecology 75:545-554.

Menges, E. S. 1990. Population viability analysis for an endangered plant. Conservation Biology 4 (1):52-62.
Miranda, F. 1958. Estudios acerca de la vegetación. Pages 213-271 in E. Beltrán. Los recursos del sureste y su aprovechamiento. Instituto Mexicano de los Recursos Renovables, Mexico, Mexico.

Newton, J. L., and E. T. Freyfogle. 2005. Sustainability: a dissent. Conservation Biology 19 (1):23-32.

O'Brien, T. G., and M. F. Kinnaird. 1996. Effect of harvest on leaf development of Asian palm Livistonia rotundifolia. Conservation Biology 10 (1):53-58.

Olmsted, I., and E. Álvarez-Buylla. 1995. Sustainable harvesting of tropical trees: demography and matrix models of two palm species in Mexico. Ecological Applications 5(2):484-500.

Padoch, C., and R. R. Sears. 2005. Conserving concepts: in praise of sustainability. Conservation Biology 19(1):39-41.

Piñero, D. M., M. Martínez-Ramos, and J. Sarukhán. 1984. A population model of Astocaryum mexicanum and a sensitivity analysis of its finite rate of increase. Journal of Ecology 72 977-991.

Popma, J., and J. Bongers. 1988. The effects of canopy gaps on growth and morphology of rain forest species. Oecologia 75:625-632.

Ramp, P. F. 1989.Natural history of Sabal minor: demography, population genetics and reproductive ecology. Dissertation, Tulane University, New Orleans, Louisiana, USA.

Ratsirarson, J., J. A. Silander, and A. F. Richar. 1996. Conservation and management of a threatened Madagascar palm species, Neodopsis decary, Jumelle. Conservation Biology 10(1):4052.

Salisbury, F. B., and C. W. Ross. 1992. Plant physiology. Wadsworth, Belmont, California, USA.

Silvertown, J. M., M. Franco, I. Pisanty, and A. Mendoza. 1993. Comparative plant demography: relative importance of life-cycle components to the finite rate of increase in woody and herbaceous perennials. Journal of Ecology 81:465-476. 
Stearns, S. C. 1992. The evolution of life histories. Oxford University Press, New York, New York, USA.

Svenning, J. C. 2001. On the role of microenvironmental heterogeneity in the ecology and diversification of neotropical rain-forest palms (Arecaceae). The Botanical Review 67(1):1-53.

Svenning, J. C., and M. J. Macías. 2002. Harvesting of Geonoma macrostachys Mart. leaves for thatch: an exploration of sustainability. Forest Ecology and Management 167:251-262.

Swart, R., P. Raskin, and J. Robinson. 2002. Critical challenges for sustainability science. Science 297: 1994.

Ticktin, T., P. Nantel, F. Ramírez, and T. Johns. 2002. Effects of variation on harvest limits for nontimber forest species in Mexico. Conservation Biology 16(3):691-705.

Turner, N. J., M. Boelscher-Ignace, and R. Ignace. 2000. Traditional ecological knowledge and wisdom of aboriginal peoples in British Columbia. Ecological Applications 10(5):12751287.

Vázquez-Yanes, C., and A. Orozco-Segovia. 1993. Patterns of seed longevity and germination in the tropical rainforest. Annual Review of Ecology and Systematics 24:69-87.

Wollenberg, E. 1998. Methods for assessing the conservation and development of forest products: what we know and what we have yet to learn. Pages 1-16 in E. Wollenberg and A. Ingles. Incomes from the forest. Methods for the development and conservation of forest products for local communities. Center for International Forestry Research (CIFOR), Bogor, Indonesia.

Zuidema, P.A., and M. J. A. Werger. 2000. Impact of artificial defoliation on ramet and genet demography in a neotropical understorey palm. Pages 109-131 in P. A. Zuidema, editor. Demography of exploited tree species in the Bolivian Amazon. Programa Manejo de Bosques de la Amazonia Boliviana and Universiteit Utrecht, Bolivia and the Netherlands. 
Appendix 1. Average transition matrices for the four study sites.

Please click here to download file 'appendix1.pdf'. 
Appendix 2. Site, year, and interaction contribution matrices. Contributions $>0.01$ are shown in boldface.

Please click here to download file 'appendix2.pdf'. 